\title{
Impact of Inadequate Urban Planning on Municipal Solid Waste Management in the Niger Delta Region of Nigeria
}

\author{
Benefit Onu ${ }^{1}$, Suresh S. Surendran ${ }^{1} \&$ Trevor Price ${ }^{1}$ \\ ${ }^{1}$ Faculty of Computing, Engineering \& Science, University of South Wales, UK \\ Correspondence: Benefit Onu, Faculty of Computing, Engineering \& Science, University of South Wales, UK. \\ Tel: 1443-654-289. E-mail: onu.benefit@southwales.ac.uk
}

Received: September 4, 2014 Accepted: September 18, 2014 Online Published: November 4, 2014

doi:10.5539/jsd.v7n6p27

URL: http://dx.doi.org/10.5539/jsd.v7n6p27

\begin{abstract}
This study examines the impact of inadequate urban planning on municipal solid waste management (MSWM) in the Niger Delta Region (NDR) of Nigeria. The continuous migration and high concentration of people, administration and industrial activities in the region with little or no implementation of urban planning procedures during the development of the settlements in the region has contributed to increase the problem of MSWM in the NDR. It is not uncommon to see streets, roads, undeveloped plots of land and drains littered with solid waste in most Niger Delta cities, towns and communities. The data for this research were gathered from field surveys, observations, questionnaires as well as desktop information from published materials. Chi-Square statistical method was used in the analysis of the correlation data. The results show that there is a strong relationship between inadequate waste collection and the existence of unplanned settlements in the region. The study also revealed that indiscriminate waste disposal is strongly linked with the existence of unplanned settlements in the NDR of Nigeria. Therefore, the implementation of urban planning procedures and inclusion of waste management during the building and development of cities, towns and villages in the Niger Delta should be taking as a matter of high priority if cities in the region are to be clean and free from wastes and environmental pollution.
\end{abstract}

Keywords: inadequate urban planning, municipal solid waste management, Niger Delta region of Nigeria

\section{Introduction}

The continuous migration and high concentration of people, administration and industrial activities in Niger Delta urban areas with little or no implementation of urban planning procedures during the development of these cities and towns, has led to the increasing problem of unsanitary municipal solid waste management (MSWM) in the region. It is not uncommon in most Niger Delta cities and towns to find streets, roads, undeveloped plots and drains littered with solid waste (Nkwocha \& Okeoma, 2009). Open dumping of solid waste (SW) is common wherever land is available. It is often done without regard to safety, health hazards and aesthetic value degradation (Botkins \& Kelly, 1998). The most intractable problem of waste management (WM) in Nigeria, especially the Niger Delta Region (NDR) is indiscriminate waste disposal and inadequate waste collection. This is exacerbated by the absence of WM infrastructure, inadequate collection of wastes, inadequate road networks and the existence of unplanned cities, towns and shanties, as well as inadequate funding, awareness and the unwholesome attitude of the masses (Nkwocha, Pat-Mbano, \& Dike, 2004; UN-HABITAT, 2010).

The provision of infrastructural facilities has declined, and intracity mobility is greatly hindered by poorly planned and inefficiently managed land use and a sharply reduced network of roads. The municipal service that has seemed to fail most strikingly as a result is waste collection and disposal. The service is frequently inadequate, with a preponderant proportion of the refuse generated remaining uncollected and with large parts of cities, particularly low-income areas, receiving little or no service. In most towns, the service is unreliable, irregular, and inefficient (Olowu, 1981; Koehn, 1992; Stren, Halfani, \& Malombe, 1994).

Housing and associated facilities (e.g. water and electricity) in the Niger Delta are similarly inadequate; millions of people now live in substandard and subhuman environments, plagued by slums, squalor, and similarly inadequate social amenities, such as poor schools, health and recreational facilities (Onibokun \& Kumuyi, 1996). Consequently most cities in Nigeria, such as Lagos, Kano, Ibadan, Aba, Warri, Benin, Onitsha and Portharcourt suffer from a culture of clutter because of the non-existence of enforceable land use and zoning laws (Napoleon, 
Kingsley, \& Joan, 2011). As a result solid waste management (SWM) has become a source of worry to many Nigerians. The state of unplanned growth and development of cities in Nigeria has compounded the issue of timely waste clearance. A habit of cleanliness begins from our homes. But sadly, in most Nigerian cities squatter settlements are predominant and residents have no easy access to waste receptacles to dispose of their garbage. Nigerian cities typically have roads and streets that are disjointed, narrow and winding. These road networks are not adequately planned with enough width and space for sidewalks; double lanes for ensuring through traffic and speed limits (Napoleon, et al., 2011).

The general neglect of infrastructure, often rationalised by the difficulty of the delta's terrain, has worsened people's access to fundamental services such as electricity, safe drinking water, roads and health facilities that are taken for granted in many other parts of the world (UNDP, 2006).

\section{Aim of the Research}

This research seeks to investigate the relationship between the existence of unplanned settlements and inadequate WM in the Niger Delta Region of Nigeria. The research will also look into the impacts of inadequate implementation of urban planning during the development of communities, towns and cities in the NDR of Nigeria, specifically the impact on MSWM in the region.

\section{Research Questions}

1) Is there any significant relationship between indiscriminate waste disposal and the existence of unplanned settlements in the NDR of Nigeria?

2) Is there any significant relationship between inadequate collection of wastes and the existence of unplanned settlements in the NDR of Nigeria?

3) Is there any significant relationship between the absence of paved and or good road network in most parts of the cities in the NDR of Nigeria and inadequate waste collection and disposal services?

\section{Research Hypotheses}

1) There is a significant relationship between indiscriminate waste disposal and the existence of unplanned settlements in the NDR of Nigeria

2) There is a significant relationship between inadequate collection of wastes and the existence of unplanned settlements in the NDR of Nigeria

3) There is a significant relationship between the absence of paved and or good road network in most parts of the cities in the NDR of Nigeria and inadequate waste collection and disposal services.

\section{Study Area}

The NDR derives its name from being situated at the mouth of the River Niger. The major traditional occupations in the region include farming and fishing, with some industries like gin distillation, textile weaving, and boat building. Other occupations include trade and transportation businesses (CEHRD, 2008).

The NDR covers about $75,000 \mathrm{~km}^{2}$ and makes up $7.5 \%$ of Nigeria's land mass. Historically and cartographically, it consists of present day Bayelsa, Delta and Rivers State. In the year 2000, during president Obasanjo's regime, Abia, Akwa-Ibom, Cross River State, Edo, Imo and Ondo States were included in the region. Over 40 million people of more than 60 ethnic groups inhabit the NDR. Ijaw which is the fourth largest ethnic group in Nigeria can be found in almost all the nine states in the Niger Delta and in some other states in the western part of Nigeria. About 250 different dialects are being spoken in the region. The region contains the world's third largest wetland, with the most extensive freshwater swamp forest and rich biological diversity. Over half of the area is criss-crossed with creeks and dotted with small islands, while the remainder is a lowland rainforest zone (UNDP, 2006). 


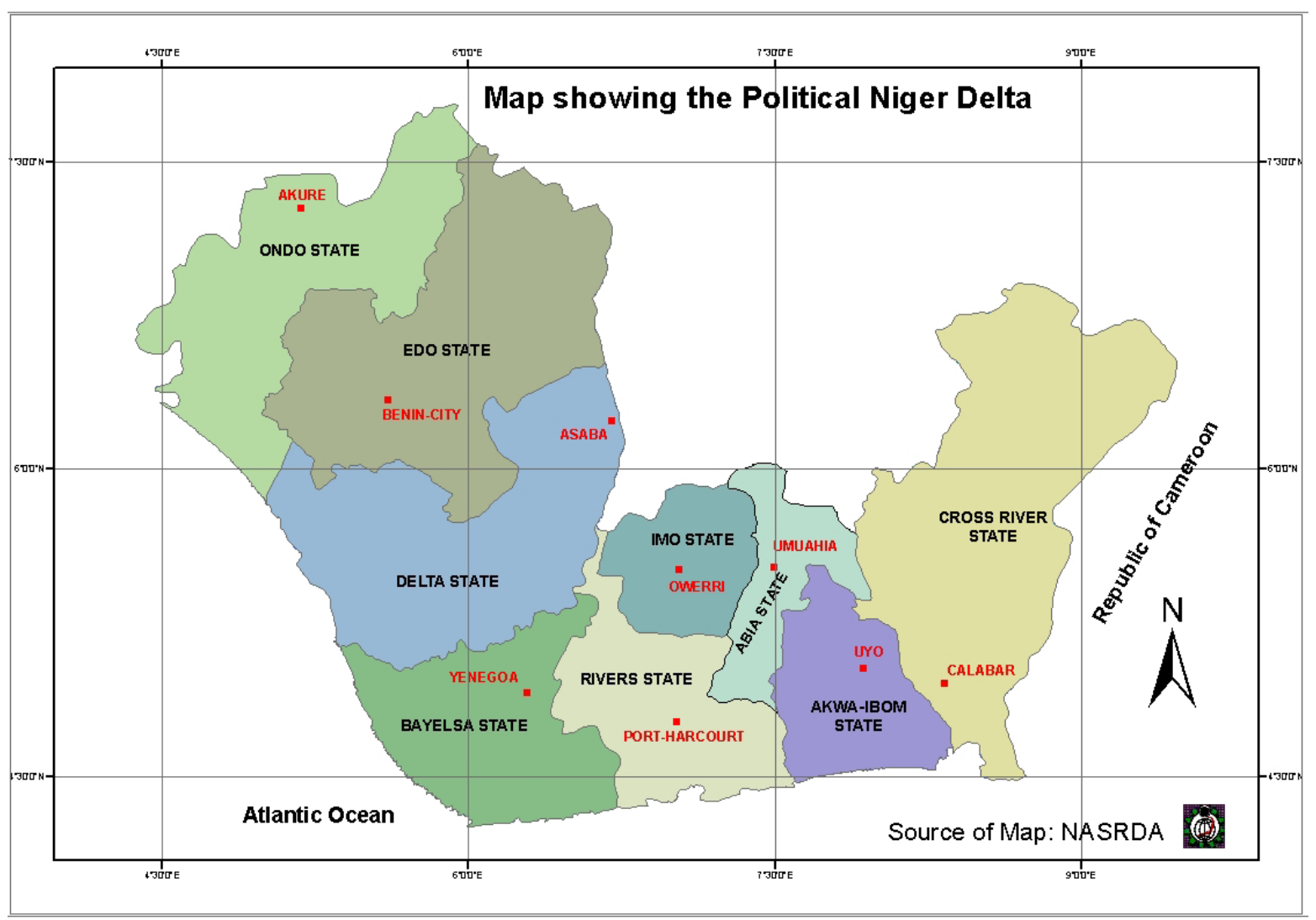

Figure 1. Map of Niger Delta region of Nigeria

\section{Method}

The data for this research were gathered from field surveys, participation and observations, questionnaires as well as desktop information from published materials. Questionnaires were distributed to 50 Ministry of Environment staff in the following states: Bayelsa, Rivers, Imo, Abia, Delta, Akwa Ibom, and Cross River. Households within these cities, towns and communities (Yenagoa, Portharcourt, Asaba, Ughele, Kiama, Amassoma, Okirika Town, Otuoke, Otuokpoti, Ewoi, Ogbia Town, Nembe, Aba, Onitsha, Owerri, Elele, Ahaoda, Uyo, Calabar) were also surveyed. Apart from the staff of the Ministry of Environment of the various States, the questionnaires were also distributed to households who live in the selected city centres, government reserved areas (GRA), suburbs of the selected cities, the selected villages and the slums within the selected cities. This was done to complement the questionnaire responses from the staff of the Ministry of Environment of the various States in the region. These urban areas were chosen because they are some of the major cities in the Niger Delta that are facing profound waste management problems and the communities (villages) were chosen because they are among the rapidly growing settlements in the region due to the influx of people who are visiting these communities for academic and business or trading reasons. Questionnaires were distributed and retrieved by hand. In all, 1,250 questionnaires were distributed and 800 copies were retrieved. The field survey and observations helped the researcher to gather first hand information (Rocco \& Plakhotnik, 2009). The field survey and observation were carried out from January 2012 to April 2012 and October 2012 to January 2013 through several visits to Niger Delta cities and communities, such as: Yenagoa, Portharcourt, Asaba, Ughele, Kiama, Amassoma, Okirika Town, Otuoke, Otuokpoti, Ewoi, Ogbia Town, Nembe, Aba, Onitsha, Elele, Ahaoda, Uyo and Calabar. The field survey and observation were carried out to ascertain the infrastructural status of the settlements, such as the standard of road networks in the cities, towns and communities, settlement structure, quality of residential houses, basic social amenities, waste management facilities, waste collection and disposal processes. This helped the researcher to understand the level of planning and development of cities and communities in the Niger Delta as well as how waste is managed in the area (Luckmann, 1996). The desktop data were analysed through content valuation method (Grbich, 2007), while Chi-Square statistical analysis was used for the analysis of the research hypotheses. 


\subsection{Chi-square $\left(X^{2}\right)$ Test}

The problem of classification of statistically significant models in a series of data has been applied to many fields of study such as intrusion detection systems, financial models, web-click records, automated monitoring systems, computational biology, cryptology, and text analysis (Agarwal, 2009; Sachan, \& Bhattacharya, 2012). An observed pattern of events is considered to be statistically significant if it is unlikely to have happened due to randomness alone (Sachan, \& Bhattacharya, 2012). In this research, the chi-square $\left(X^{2}\right)$ was used as a quantitative statistical tool to measure the statistical significance relationship between inadequate urban planning and MSWM in the Niger Delta. Statistical significance is used to determine whether the outcome of a given experiment can be ascribed to some unrelated factors or is solely due to chance (Sachan, \& Bhattacharya, 2012).

Chi-square test is an inferential statistics method designed to test for significant relationships between two variables arranged in a bivariate table (Agarwal, 2009; Sachan, \& Bhattacharya, 2012). Chi-square requires no assumptions about the shape of the population distribution from which a sample is drawn. However, like all inferential methods it assumes random sampling. It can be applied to nominal or ordinal variables (Denise \& Vandenbogaert, 2001; Agarwal, 2009; Sachan, \& Bhattacharya, 2012).

The sampling distribution of $X^{2}$ tells the probability of getting values of $X^{2}$, assuming no relationship exists in the population (Dutta \& Bhattacharya, 2010). The $\mathrm{X}^{2}$ sampling distributions depend on the degrees of freedom. The $\mathrm{X}^{2}$ sampling distribution is not one distribution, but is a family of distributions. Chi-square values are always positive. The minimum possible value is zero, with no upper limit to its maximum value. As the number of degrees of freedom increases, the distribution becomes more symmetrical (Goonatilake, Herath, Herath, Herath, \& Herath, 2007; Dutta \& Bhattacharya, 2012).

Chi-square follows five basic steps which include: a) making assumptions (random sampling), b) stating the research and null hypotheses and selecting alpha value, c) selecting the sampling distribution and specifying the test statistic, d) computing the test statistic and e) making a decision and interpreting the results (Denise \& Vandenbogaert, 2001; Agarwal, 2009; Sachan, \& Bhattacharya, 2012).

In $\mathrm{X}^{2}$ statistical technique, the research hypothesis $\left(\mathrm{H}_{1}\right)$ proposes that the two variables are related in the population while the null hypothesis $\left(\mathrm{H}_{0}\right)$ states that no relationship exists between the two cross-tabulated variables in the population, consequently the variables are statistically independent (Agarwal, 2009; Sachan, \& Bhattacharya, 2012).

The mathematical process involved is given in the formula:

$$
x^{2}=\sum \frac{(0-E)^{2}}{E}
$$

Where $\mathrm{X}^{2}=$ chi-square, $\mathrm{O}=$ the observed value and $\mathrm{E}=$ the expected value

For each class of observations, the deviation of the observed value is calculated from the expected value. The deviation is then squared and divided by the expected value. Then all of the values are summed. The smaller the differences between the observed and the expected values, the smaller the value of $X^{2}$ will be and, conversely, the greater the difference the greater the value of $X^{2}$ (Denise \& Vandenbogaert, 2001; Agarwal, 2009; Sachan, \& Bhattacharya, 2012).

The Degrees of Freedom (DF) is determined as follows:

$\mathrm{DF}=(\mathrm{m}-1)(\mathrm{n}-1)$

Where $m=$ the number of rows and $n=$ the number of columns.

The p-value is the probability of obtaining a test statistic at least as extreme as the one that was actually observed assuming the null hypothesis to be true (Sachan, \& Bhattacharya, 2012). In this research, the p-value or the alpha level is $0.05(5 \%)$.

\subsection{Limitations of the $X^{2}$ Test}

- The chi-square test does not give us much information about the strength of the relationship or its substantive significance in the population.

- The chi-square test is sensitive to sample size. The size of the calculated chi-square is directly proportional to the size of the sample, independent of the strength of the relationship between the variables.

- The chi-square test is also sensitive to small expected frequencies in one or more of the cells in the table. 


\section{Urbanisation and Waste Management}

Urbanisation has occurred rapidly in the last few decades, about half the world's population are now living in urban areas due to the increase in competitiveness among countries and cities in the world to gain their place in the global market and diplomatic relevance (Cohen, 2004; Tacoli, 2012; Marshall \& Farahbakhsh, 2013). At the start of the $20^{\text {th }}$ century, only about 16 cities in the world were inhabited by about one million people and most of these cities were in the developed countries. But at the beginning of the $21^{\text {st }}$ century, about 400 cities were inhabited by over one million people and about three-quarters of these new urban areas were developed in low and middle income countries (Cohen, 2004; Marshall \& Farahbakhsh, 2013). This rapid development of urban centres in the low and middle income countries is generally not properly planned. This has resulted to several land use and infrastructural problems that have bedeviled SWM services in the developing countries (Cohen, 2004).

It is projected that most of the world's population growth will occur in urban areas from now until 2050 and the world's poorer countries will have the highest increase during this period (Cohen, 2004; Marshall \& Farahbakhsh, 2013). Considering the poverty level of these developing countries and the incapability of the governments of these countries to provide adequate social amenities and other infrastructure to the inhabitants of these huge cities, more people will be forced to live in slums and other places where sanitary situations are awful and WM services are not available or are inadequate (UNFPA, 2011; Tacoli, 2012; Marshall \& Farahbakhsh, 2013). The SWM demands of these highly populated low income settlements are generally inadequate and nonexistence in most cases, despite the fact that these areas need WM services most since they do not have enough space within the haphazardly built houses for waste burial or composting, hence, they dispose their wastes indiscriminately (Coffey \& Coad, 2010; Marshall \& Farahbakhsh, 2013).

Waste collection services in these slums are usually not available or inadequate, due to the unplanned nature of the settlements, lack of space for refuse containers and waste collection trucks, narrow meandering and unpaved roads with steep slopes (Coffey \& Coad, 2010; Henry, Yongsheng, \& Jun, 2006; Onu, Trevor, Suresh, \& Ebie, 2012; Onu, Trevor, \& Suresh, 2014). This inadequate waste collection in the slums has resulted in the increase indiscriminate waste disposal in any available land and into surface water bodies, resulting to water and soil pollution with series of environmental and human health risks (Konteh, 2009; Coffey \& Coad, 2010; Tacoli, 2012; Onu, et al., 2012; Onu, et al., 2014).

Implementing a WM programme involves consideration of regulations concerning land use. Land use zoning is a requisite process in urban development (EPA, 1999; World Bank/METAP, 2002). Land zoning divides local territorial land mass into several sectors through regulations that provides specifications for land usage: such as residential areas, industrial and commercial areas, forest reserves, recreational and tourism sites as well as infrastructural and social amenities location (EPA, 1999; World Bank/METAP, 2002). Urban development planning should integrate all the society's land use needs in a sustainable manner. This involves the development of a land use plan and the evaluation of the planning application process (United Towns Development Agency, 1996).

The location of WM sites and infrastructure/facilities within an urban land use plan has been burdened with series of technical, environmental, economic and socio-political issues. WM facility siting usually face stringent opposition from local citizens, resulting in the shortage of available WM facilities. In any case, it is important that WM strategies be included and implemented in urban development planning programme (EPA, 1999; World Bank/METAP, 2002). Hence, for land used planning to be considered adequate, it should provide this key need in an integrated manner. It is important that land use planning should provide adequate guidance for the location of WM facilities within the planned area. This should include specific targets specified in the WM strategy for the said area with the required planning procedures (United Towns Development Agency, 1996; EPA, 1999; World Bank/METAP, 2002).

Land use should be allocated in accordance to the expected future use, and all urban development planning within the urban area should be in line with the land use plan. This is important because, as the urban area develops and expands, the land use plan will be useful to planners and decision makers in the management and development of the urban centre in an integrated and organised manner rather than in a haphazard way (World Bank/METAP, 2002). Land use plan also gives planners and decision makers the room to develop and expand the urban centre sustainably through the integration of environmental, technological, economical and sociopolitical concerns of citizens in the planning and implementation process of projects (EPA, 1999; World Bank/METAP, 2002). 


\section{Waste Management in the Niger Delta Region of Nigeria}

The NDR is underdeveloped, despite the fact that it is the bread basket of Nigeria. Whittington (2001) aptly described the economic dilemma of the region stating that "the oil region in Nigeria seems to be stuck in a time warp, with little real change since oil was discovered 45 years ago. Away from the main towns, there is no real development, no roads, no electricity, and no running water".

Indiscriminate solid waste disposal is a menace and embarrassment to Niger Delta cities (Isu, 2005). About 70 to 80 percent of solid wastes generated in Niger Delta cities are either deposed on road sides, illegal dumpsites, in water ways, or in open dumpsites which adversely affect the environment. SW also poses risks to public health and adversely affects flora and fauna, especially when it is not appropriately collected and disposed (Geraldu, 1995). The poor state of SWM in Niger Delta cities is caused by inadequate facilities, poor funding, and poor implementation of policies as well as unsustainable lifestyle such as consumption pattern. According to Egunjobi (1986), the problem of ineffective SWM in the Niger Delta is closely linked with poor social services delivery efforts which cause unnecessary delays in solid waste clearance. Broken down machinery, poor maintenance of dumpsites, poorly maintained urban streets and roads and irregularities in the designation of sanitary landfill sites are all problems. Studies have revealed that households account for about half of the solid wastes generated, by weight in the Niger Delta cities (Geraldu, 1995; Isu, 2005).

SWM has received considerable attention in the Niger Delta and Nigeria generally in recent years. Despite this laudable attention, collection, disposal, processing, treatment, recycling and utilisation have defied solution as a result of the attitude of the people. The waste disposal habit of the people, corruption, work attitude, inadequate plants and equipment among others are the major factors militating against effective SWM in the Niger Delta (Geraldu, 1995; Isu, 2005). The major effects of poor SWM in Niger Delta cities include: blocked drains, flooding, traffic congestion, soil pollution, air pollution, surface water pollution, health problems, un-aesthetic dumpsites and loss of community pride.

In most Niger Delta cities about, about $80 \%$ of the population does not receive waste collection services (Nabegu, 2010). During year 2006 to 2013, WM in Portharcourt, Calabar city and Uyo have improved though; more is still needed to cover the suburbs of the cities and the villages which receive little or no waste collection services. Waste collection services are impeded by the inaccessibility nature of most parts of the cities, suburbs and villages due to the poor nature of roads, unplanned settlements (slums), marshy and the overall terrain characteristics as well as inadequate personnel and inadequate waste collection vehicles (UNDP, 2006; Nabegu, 2010). In the NDR of Nigeria like other parts of Nigeria, villages and communities outside the state capital are not usually considered for waste collection services or any other WM program (Wolfville \& Scotia, 2002; Ezeah, Roberts, Watkin, Philips, \& Odunfa, 2009). The most widely used method of waste collection in the region is from street to street (collection point to collection point). These collection points are situated at strategic places in the city where people can bring their wastes on a daily or weekly basis depending on the operation policy adopted by the state.

Composting practice is not prominent in the NDR of Nigeria. Though, the waste stream of the region is composed of about $30-50 \%$ of compostable materials with high moisture content (Ogwueleka, 2009). The absence of a market for compost and absence of composting plants in the region has further discouraged composting practice. Farmers in the region are not using soil enhancers to improve the soil. Although, a few farmers do use organic manure from co-mingled wastes to enhance the soil fertility in their farms but it is been practiced in a rudimentary manner. Recently, with the awareness program run by the federal and state ministries of agriculture and the introduction of easy means of accessing inorganic fertilizers from government with a subsidised cost, some farmers in the region have started using inorganic fertilizers as soil enhancers for their crops. This development might drove up the composting market in the region in the near future.

In the NDR, there are no operational engineered landfills (Agunwamba, 1998; Remigios, 2010). The practice of disposing co-mingled wastes without treatment or segregation is yet to be handled properly in the region (Imam, Mohammed, Wilson \& Cheeseman, 2008). The absence of engineered landfills coupled with other WM inadequacies is encouraging indiscriminate waste disposal in the NDR.

In the NDR of Nigeria, there are also no recycling plants. Recycling and recovery of wastes is done by waste scavengers who collect recyclable wastes to sell. Waste scavengers normally climb on the waste collection vehicles to gain access to recyclable wastes as the wastes are been taken to the dumpsite. The scavengers are also found at illegal dumpsites and anywhere that they can find recyclable materials (Ogwueleka, 2009; Mwesigye, et al., 2009). The activities of scavengers and informal recycling and recovery practices in the NDR are yet to receive the desired regulation and support from government and private companies (Odunfa, 2007). 


\section{Town planning and Settlement Patterns in the Niger Delta Region of Nigeria}

Settlement patterns in the Niger Delta are influenced by topography and drainage (UNDP, 2006). In the coastal beach ridge zone, dry land is available, though in narrow strips. Settlements in this area typically stretch along the coast (UNDP, 2006). Estuaries tend to separate settled areas. A number of sizeable settlements, such as Bonny, Akassa and New Forcados, are located here. Given the fact that the mangrove swamp zone is a swamp with scattered islands, the human population is sparsely distributed. The swamp is virtually uninhabited except for fishing camps; some settlements exist on dry islands. Settlement size is dependent on the size of the given island. Large settlements include Buguma, Nembe and Burutu. Since much of the land is swampy, habitation is usually in areas of high dry land. The levees along the rivers and creeks are favoured sites, and often densely populated. Other areas are sparsely settled. Major settlements include Sagbama, Oleh and Patani. Of all the zones, the lowland rainforest zone provides the best places for settlement. Most of the large settlements are found here, however, towns like Port Harcourt and Warri are found in the transition zone between swamp land and the more solid land of the lowland rainforests (UNDP, 2006).

Small settlements with less than 3,000 people dominate the Niger Delta, followed by settlements in the range of 4,000 to 5,000 people. The Niger Delta Development Commission (NDDC) Regional Master Plan had that there are about 13,329 settlements in the region, and 94 per cent of these have populations of less than 7,000. Only about 98 settlements, or one per cent, can be regarded as urban centres based on population size. The prevalence of small settlements is explained by a number of factors. First, the environment provides limited space for human settlement, given the fragmentation of land into islands and the occurrence of dry land in isolated pockets. Most settlements are small and dispersed. Second, fishing communities all over the world characteristically dwell in small fishing villages close to their fishing grounds. Third, as indicated above, the Niger Delta is home to many small minority groups, each of which is composed of numerous clans. Each clan cherishes its own private space (Mabogunje, 1965; UNDP, 2006). Unfortunately, this phenomenon has often fostered inequality in development between urban and rural areas. This is especially true in Nigeria, where many of the cities are perceived as parasitical absorbing resources without spreading development to surrounding rural areas. In particular, large settlements with populations of 40,000 or more are few in the Niger Delta.

Stem from the scarcity of dry and relatively well-drained land, especially in the barrier island forest, mangrove and freshwater swamp forest zones. This has made housing and settlement development very difficult and costly, and to some extent accounts for neglect of the region by successive governments. The dynamics of flood and tidal movement further reduce available land space, forcing many communities to engage in uncontrolled land reclamation with negative environmental impacts. 

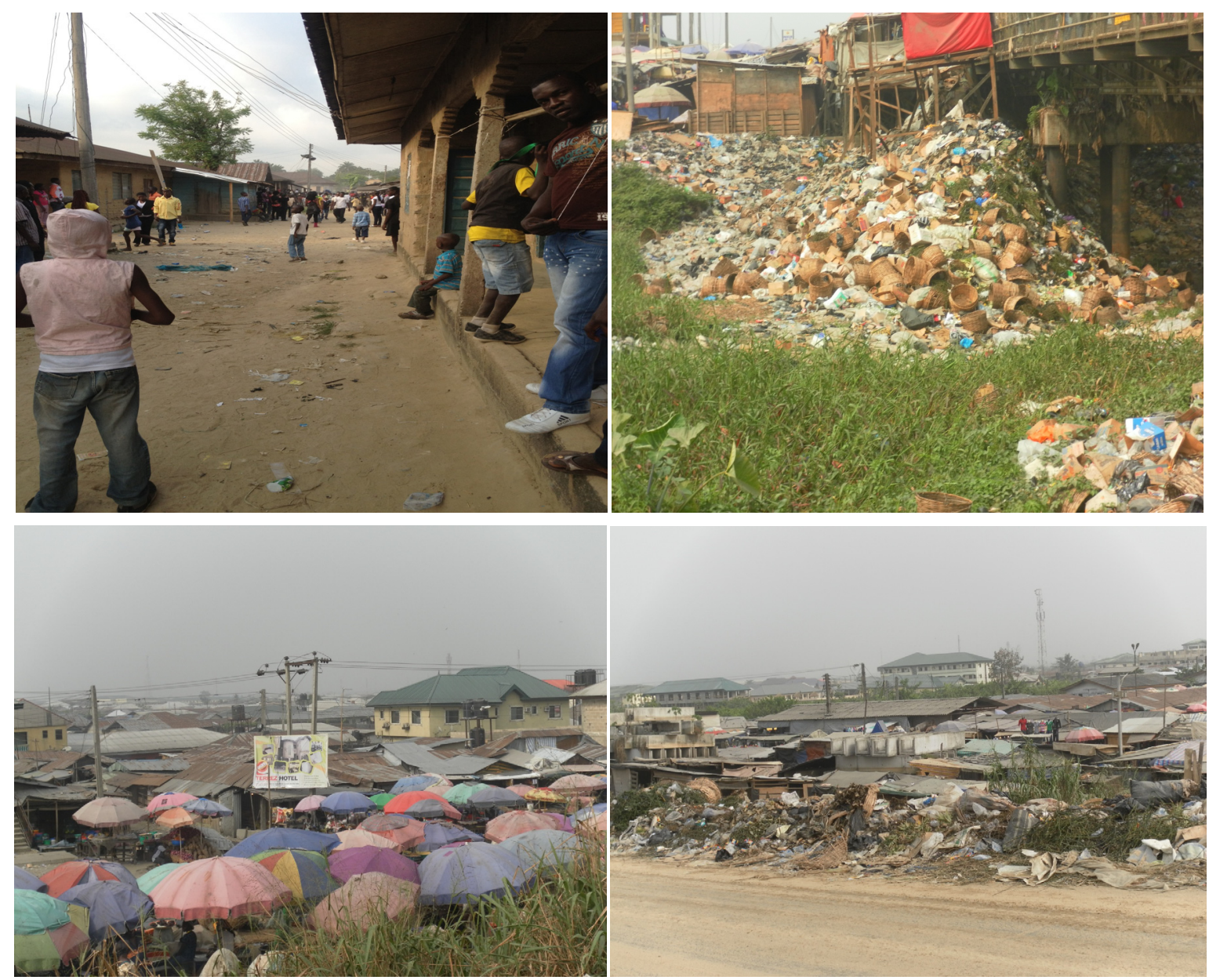

Figure 2. Housing pattern in a typical Niger Delta village and slum settlements

Source: Author's fieldwork photos, (2012)
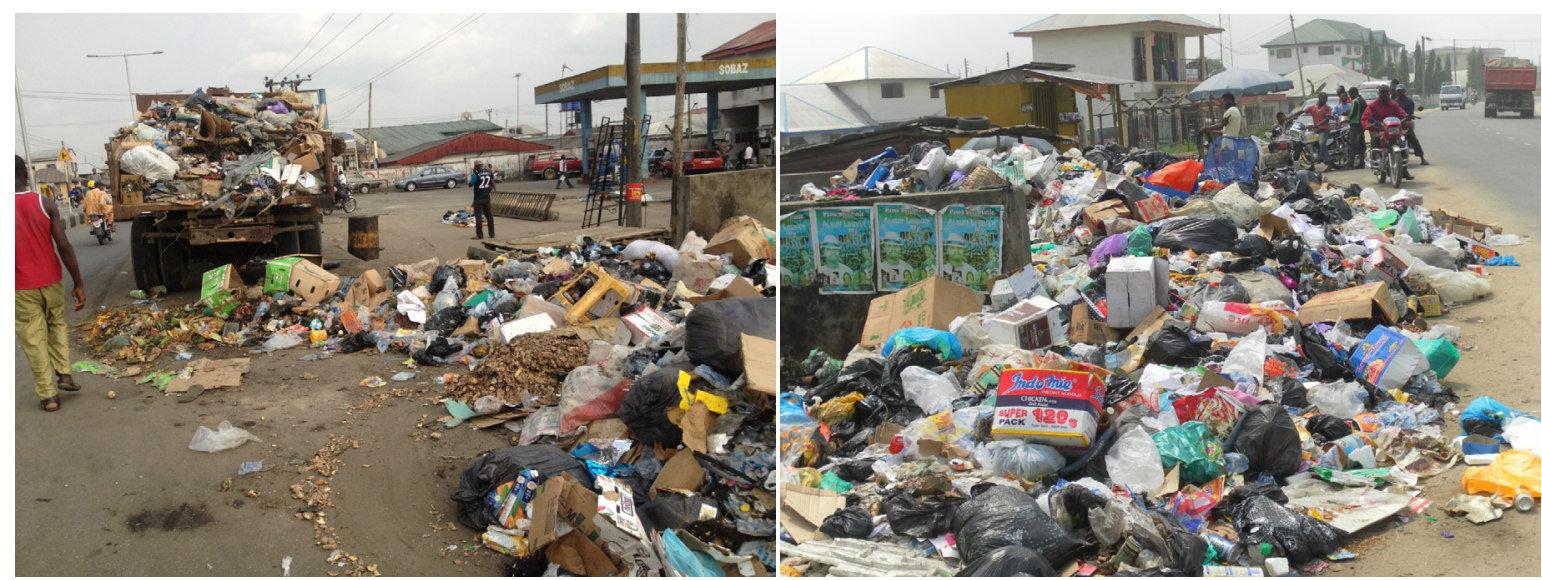

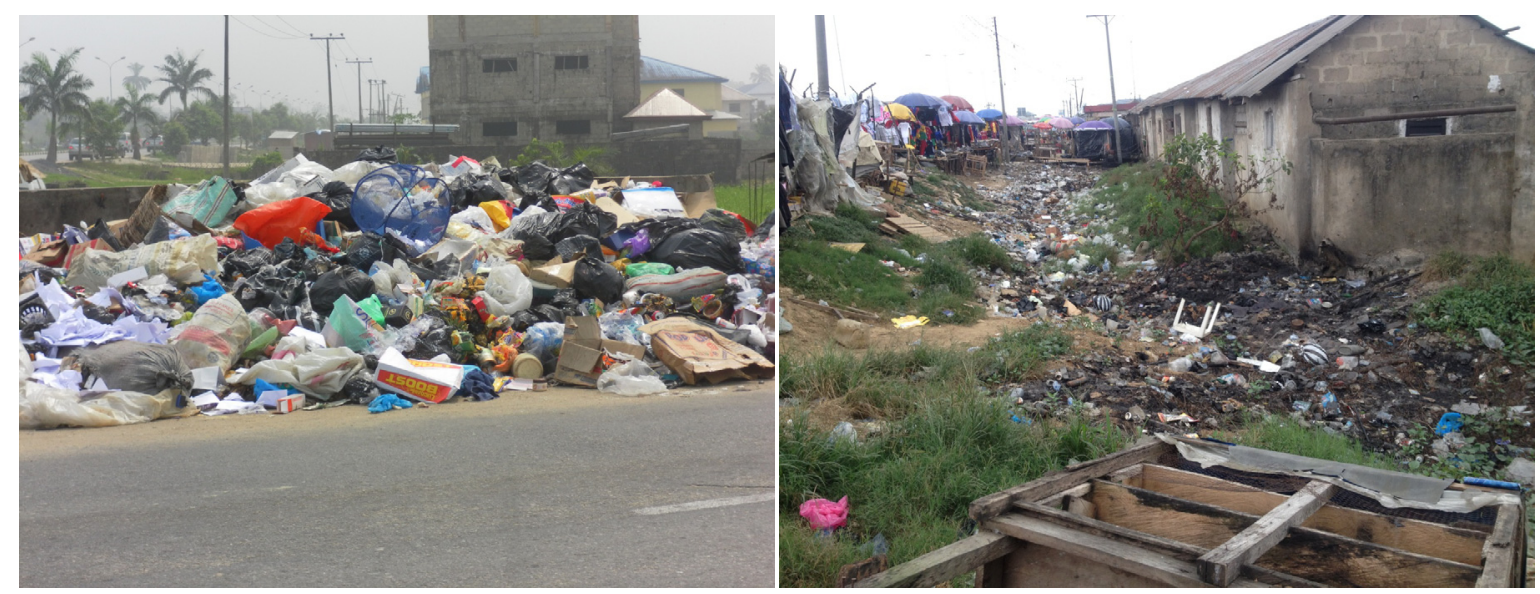

Figure 3. Evidence of inadequate waste management in a typical Niger Delta city

Source: Author's fieldwork photos, (2012)

Table 1. Size distribution of settlements in the Niger Delta

\begin{tabular}{lllll}
\hline NDDC states & Less than 1,000 people & $1,000-5,000$ people & $5,000-20,000$ people & 20,000 people and above \\
\hline Abia & 393 & 494 & 52 & 11 \\
Akwa Ibom & 1,236 & 1,098 & 46 & 7 \\
Bayelsa & 290 & 317 & 85 & 4 \\
Cross River & 117 & 500 & 56 & 8 \\
Delta & 1,016 & 307 & 104 & 22 \\
Edo & 903 & 264 & 70 & 11 \\
Imo & 788 & 925 & 81 & 2 \\
Ondo & 1,463 & 278 & 57 & 16 \\
Rivers & 428 & 598 & 213 & 17 \\
Niger Delta & 7,686 & 4,781 & 764 & 98 \\
\hline
\end{tabular}

Source: Centre for Population and Environment Development (CPED), 2003

\section{Road Network and Transportation in Niger Delta Region}

Planning shapes the places where people live and work and the country we live in. It plays a key role in supporting the Government's wider economic, social and environmental objectives and for sustainable communities (Communities and Local Governments, 2011).

Nigeria's about 194,000 km network of roads has deteriorated over time. Bad roads are now one of the major causes for road deaths in Nigeria. Nigerian roads remains poor for a number of reasons such as faulty designs, lack of drainage and very thin coatings that were easily washed away, excessive use of the road network given the under-developed nature of waterways and railways among others (Obafemi, Eludoyin, \& Opara, 2011). Most Niger Delta roads are notable through their meandered and large portions of crumbled main and arterial highways. Roads in the region, where they exist at all are often impassable. The building of good road network connecting entire NDR of Nigeria and the rest of the country is viewed as the beginning of economic development and emancipation in the region.

In 1998, NDDC proposed the construction of an East-West coastal road. To further emphasize the strategic importance of the road, the international conference on the development of the NDR held in Port Harcourt from the December 10-12, 2001, under the aegis of NDDC and UNDP concluded that without the proposed road, no meaningful development would likely take place in the region.

The NDR holds about $30 \%$ of the country's population, yet only 17.6 percent of the country's length of roads is situated in the region. Niger Delta Regional Development master plan should address this paucity of 
transportation infrastructure. The region will be greatly transformed if roads in the region are paved. The precarious situation of the region is further worsened by infrastructure deficit made worse by inclement marshy and mangrove forest terrains that severely hamper movement and access to settlements in the riverine areas.

Niger Delta roads are mostly bad and they are usually impassable during the rainy season. Efforts by local government authorities to repair the roads have worsened them and left the local people with more hardship. Although urban road transportation development has recently been accorded some priority attention, less regard has been shown for rural transportation, especially water transport, which the majority of the rural populace depend on. Transport and communication in the area is miserable, requiring people to trek long and excruciating distances due to the high cost of motorcycle transport, which is one of the most popular means of transport. The few available roads have many large and deep potholes that motorists avoid them; and most of the roads are in a deplorable state of disrepair (UNDP, 2006).

\section{Results and Discussion}

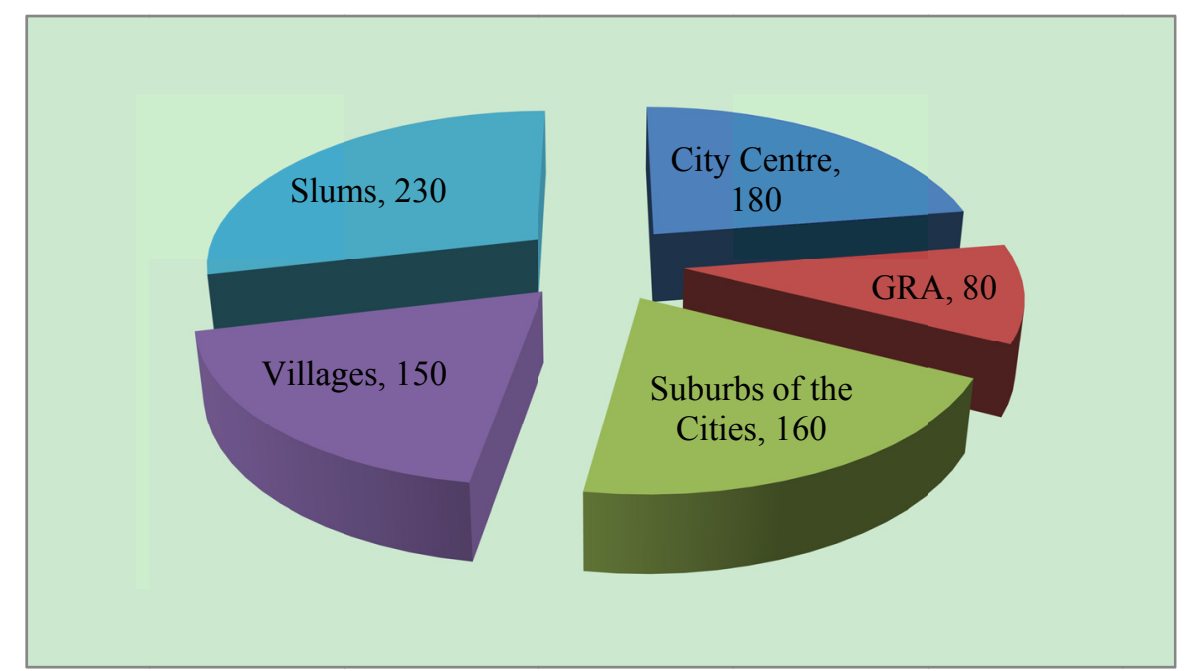

Figure 4. Distribution of respondents by places of residence

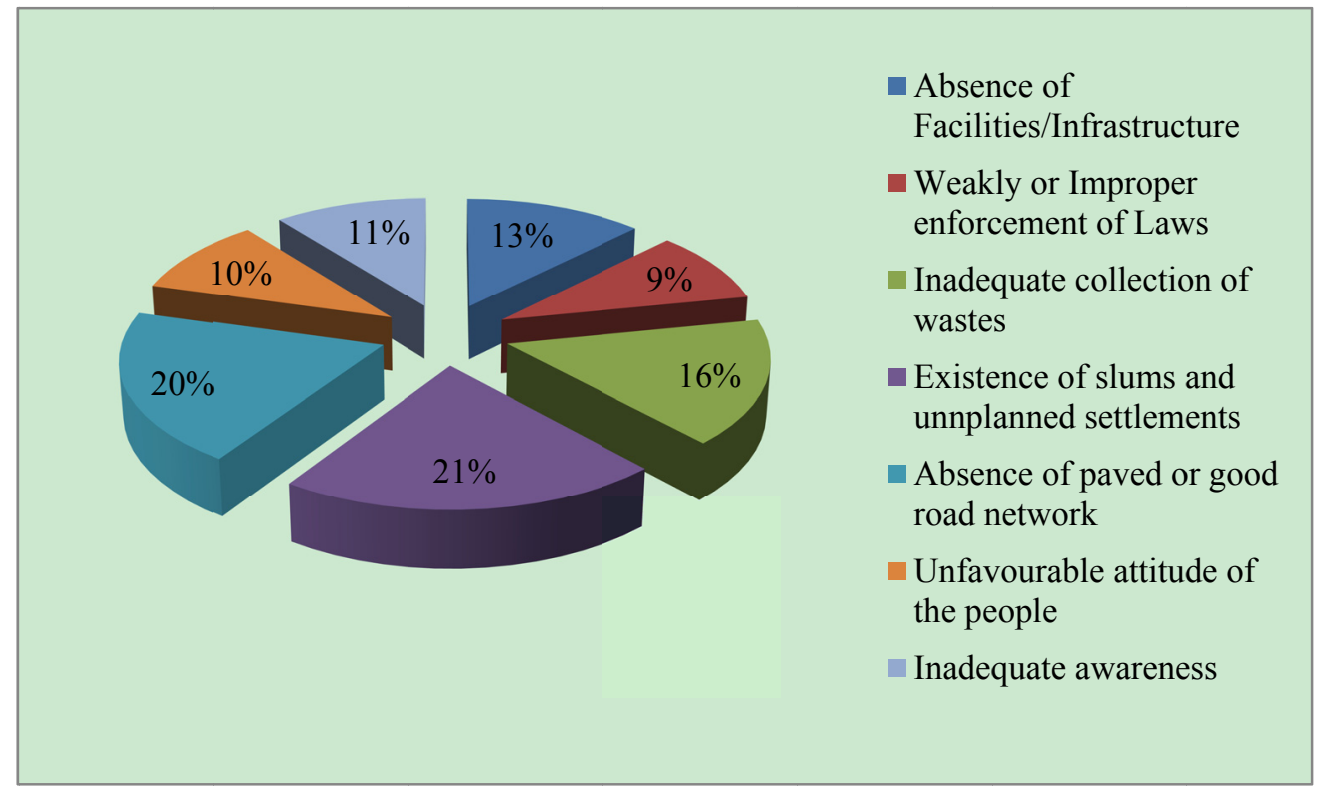

Figure 5. Causes of indiscriminate waste disposal in the Niger Delta region of Nigeria 


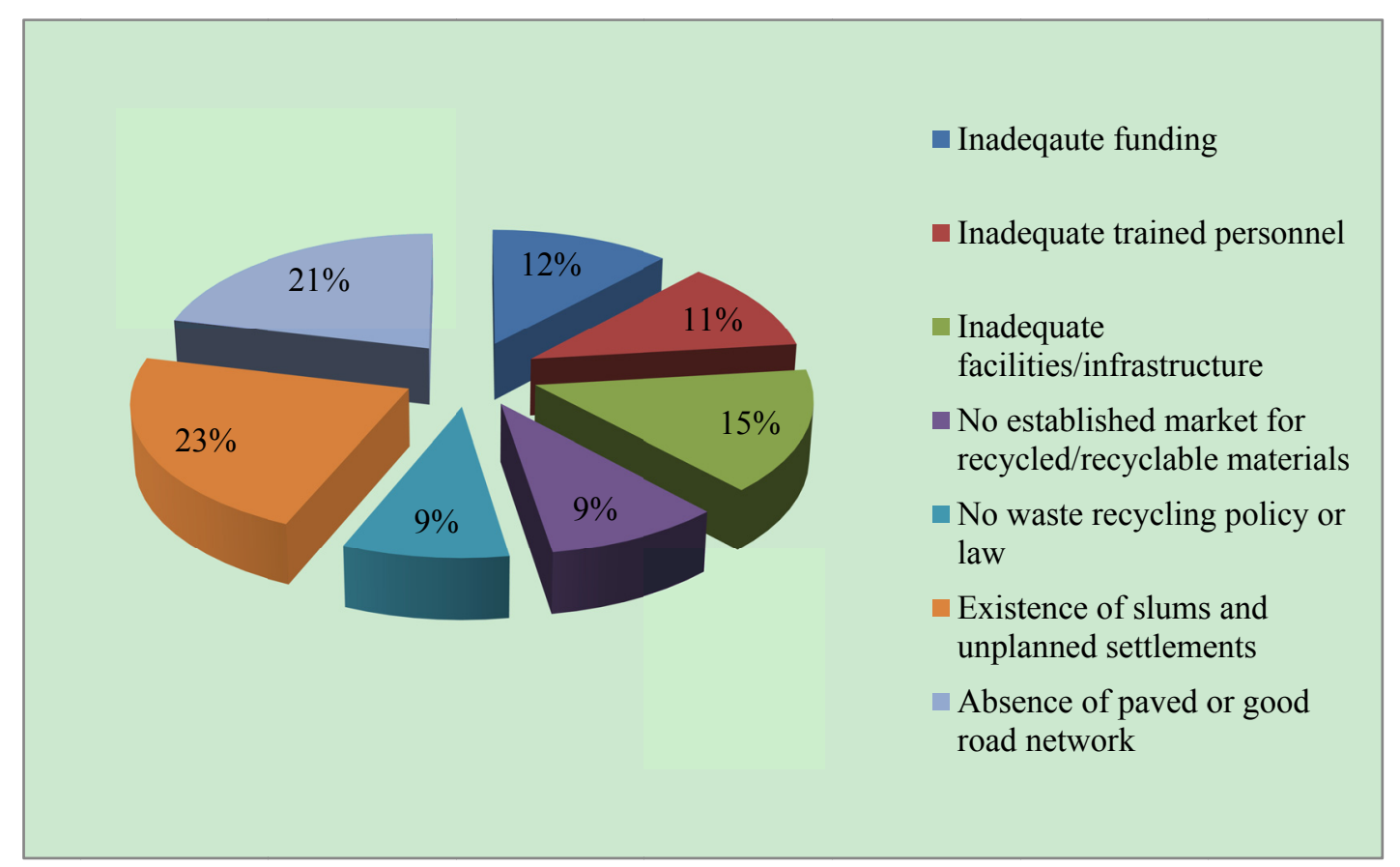

Figure 6. Causes of inadequate waste collection in the Niger Delta region of Nigeria

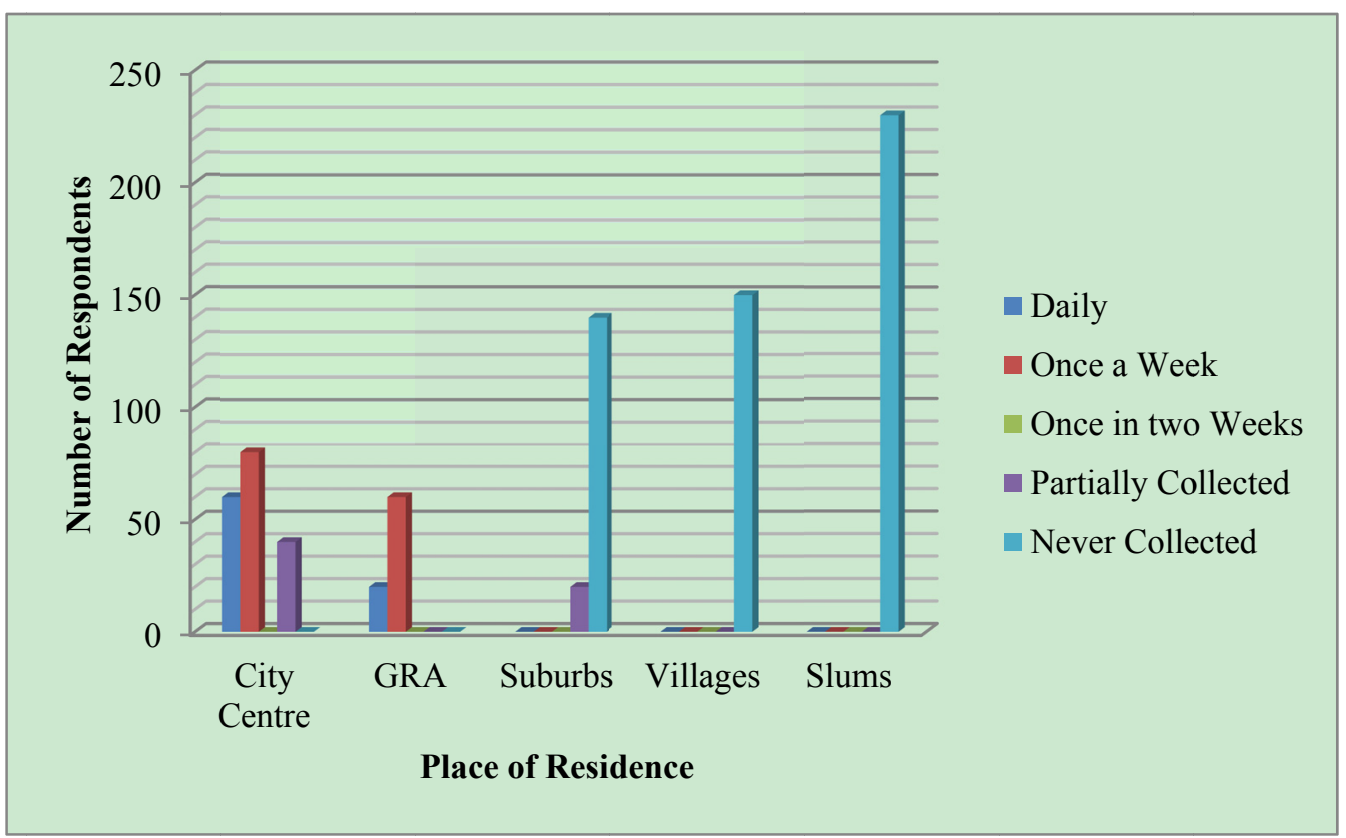

Figure 7. Waste collection services by places of residence in the Niger Delta region 


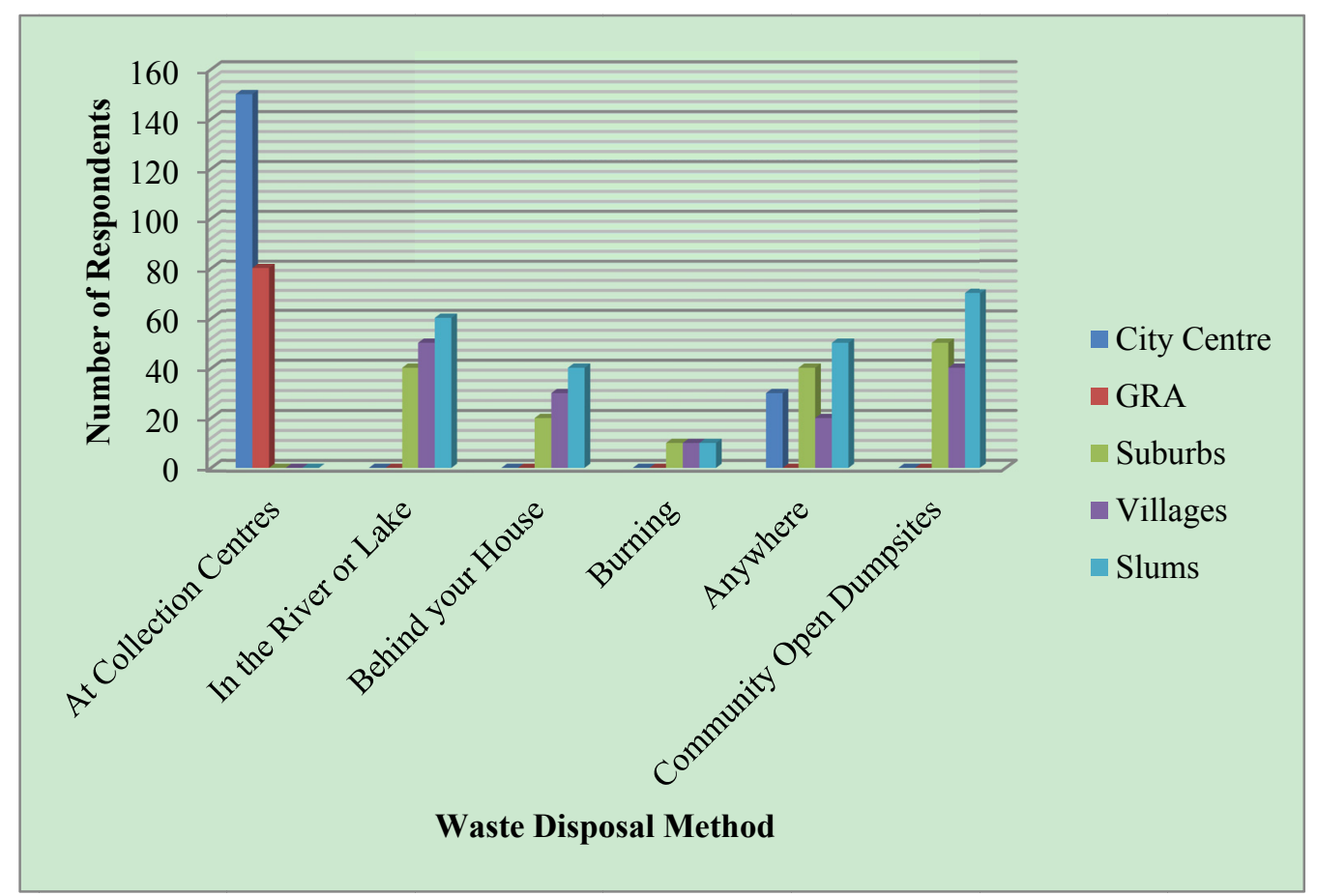

Figure 8 . Waste disposal method by places of residence in the Niger Delta region

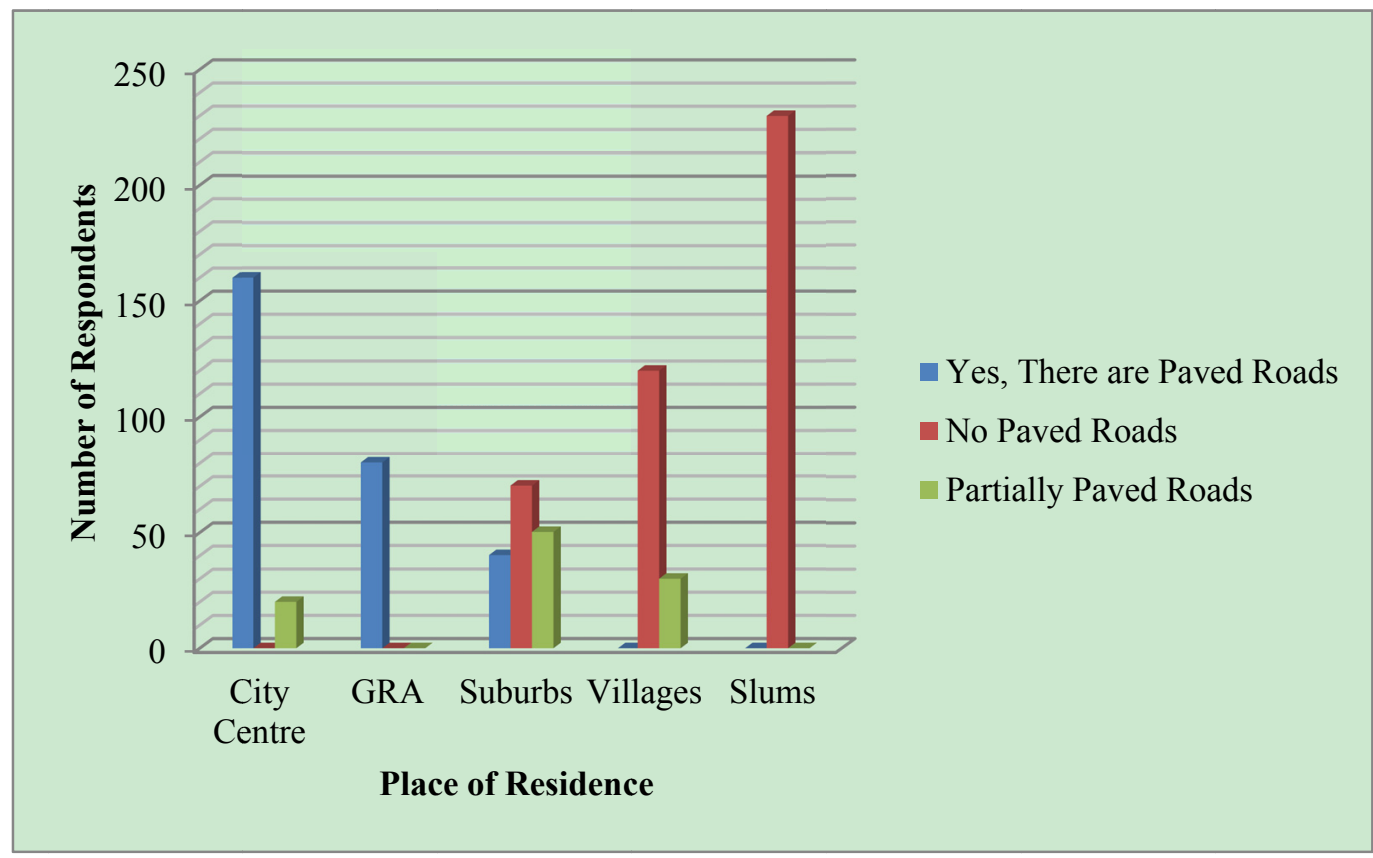

Figure 9. Availability of paved or good road network by places of residence in the Niger Delta region 


\subsection{Chi-Square Results}

Table 2. Analysis of hypothesis one $\left(\mathrm{H}_{1}\right)$

\begin{tabular}{|c|c|c|c|c|c|c|c|}
\hline \multirow[t]{2}{*}{ Formula } & \multirow[t]{2}{*}{ Category of Respondents } & \multicolumn{5}{|c|}{ Response Options } & \multirow[t]{2}{*}{ Total } \\
\hline & & Daily & Once a week & Once in two weeks & Partially collected & Never collected & \\
\hline \multirow[t]{6}{*}{$\mathbf{O}$} & City centre & 60 & 80 & 0 & 40 & 0 & 180 \\
\hline & GRA & 20 & 60 & 0 & 0 & 0 & 80 \\
\hline & Suburbs & 0 & 0 & 0 & 20 & 140 & 160 \\
\hline & Villages & 0 & 0 & 0 & 0 & 150 & 150 \\
\hline & Slums & 0 & 0 & 0 & 0 & 230 & 230 \\
\hline & Total & 80 & 140 & $\mathbf{0}$ & 60 & 520 & 800 \\
\hline \multirow[t]{5}{*}{$\mathbf{E}$} & City centre & 18 & 31.5 & 0 & 13.5 & 117 & \\
\hline & GRA & 8 & 14 & 0 & 6 & 52 & \\
\hline & Suburbs & 16 & 28 & 0 & 12 & 104 & \\
\hline & Villages & 15 & 26.25 & 0 & 11.25 & 97.5 & \\
\hline & Slums & 23 & 40.25 & 0 & 17.25 & 149.5 & \\
\hline \multirow[t]{5}{*}{ O - E } & City centre & 42 & 48.5 & 0 & 26.5 & -117 & \\
\hline & GRA & 12 & 46 & 0 & -6 & -52 & \\
\hline & Suburbs & -16 & -28 & 0 & 14 & 36 & \\
\hline & Villages & -15 & -26.25 & 0 & -11.25 & 52.5 & \\
\hline & Slums & -23 & -40.25 & 0 & -17.25 & 80.5 & \\
\hline \multirow[t]{5}{*}{$(\mathrm{O}-\mathrm{E})^{2}$} & City centre & 1764 & 2352.25 & 0 & 702.25 & 13689 & \\
\hline & GRA & 144 & 2116 & 0 & 36 & 2704 & \\
\hline & Suburbs & 256 & 784 & 0 & 196 & 1296 & \\
\hline & Villages & 225 & 689.06 & 0 & 126.56 & 2756.25 & \\
\hline & Slums & 529 & 1620.06 & 0 & 297.56 & 6480.25 & \\
\hline \multirow[t]{5}{*}{$(\mathrm{O}-\mathrm{E})^{2} / \mathrm{E}$} & & 98 & 74.68 & $\mathbf{0}$ & 52.02 & 117 & \\
\hline & & 18 & 151.14 & $\mathbf{0}$ & 6 & 52 & \\
\hline & & 16 & 28 & $\mathbf{0}$ & 16.33 & 12.46 & \\
\hline & & 15 & 26.25 & $\mathbf{0}$ & 11.25 & 28.27 & \\
\hline & & 23 & 40.25 & $\mathbf{0}$ & 17.25 & 43.35 & \\
\hline
\end{tabular}

$D F=(m-1)(n-1)=(5-1)(5-1)=4^{*} 4=16$, Alpha level of 0.05, Table value is 26.30, Calculated value is 846.25

$\mathbf{H}_{1}$ : There is a significant relationship between inadequate collection of wastes and the existence of unplanned settlements in the NDR of Nigeria.

The purpose of this hypothesis is to determine through Chi-Square analysis if the existence of unplanned settlements is impacting negatively on waste collection services in the NDR of Nigeria. The table value from the Chi-Square analysis is 26.30 at an alpha level of 0.05 , with a degree of freedom (DF) of 16 . This shows that the calculated value of 846.25 is greater than the critical table value. Since the calculated Chi-Square value is greater than the critical table value, thus, the hypothesis $\left(\mathrm{H}_{1}\right)$ which says that there is a significant relationship between inadequate collection of wastes and the existence of unplanned settlements in the NDR of Nigeria is accepted. Therefore, we conclude that there is a relationship between inadequate collection of wastes and the existence of unplanned settlements in the NDR of Nigeria. 
Table 3. Analysis of hypothesis two $\left(\mathrm{H}_{2}\right)$

\begin{tabular}{|c|c|c|c|c|c|c|c|c|c|}
\hline \multirow{2}{*}{$\begin{array}{l}\text { Formu } \\
\text { la }\end{array}$} & \multirow{2}{*}{$\begin{array}{ll}\text { Category } & \text { of } \\
\text { Respondents } & \\
\end{array}$} & \multicolumn{7}{|c|}{ Response Options } & \multirow{2}{*}{$\begin{array}{l}\text { Tot } \\
\text { al }\end{array}$} \\
\hline & & $\begin{array}{l}\text { At collection } \\
\text { centres }\end{array}$ & $\begin{array}{l}\text { In the river } \\
\text { or lake }\end{array}$ & $\begin{array}{l}\text { Behind your } \\
\text { house }\end{array}$ & $\begin{array}{l}\text { Burni } \\
\text { ng }\end{array}$ & $\begin{array}{l}\text { Anywh } \\
\text { ere }\end{array}$ & $\begin{array}{l}\text { Community } \\
\text { dumpsites }\end{array}$ & open & \\
\hline \multirow[t]{6}{*}{ O } & City centre & 150 & 0 & 0 & 0 & 30 & 0 & & 180 \\
\hline & GRA & 80 & 0 & 0 & 0 & 0 & 0 & & 80 \\
\hline & Suburbs & 0 & 40 & 20 & 10 & 40 & 50 & & 160 \\
\hline & Villages & 0 & 50 & 30 & 10 & 20 & 40 & & 150 \\
\hline & Slums & 0 & 60 & 40 & 10 & 50 & 70 & & 230 \\
\hline & Total & 230 & 150 & 90 & 30 & 140 & 160 & & 800 \\
\hline \multirow[t]{5}{*}{$\mathbf{E}$} & City centre & 51.75 & 33.75 & 20.25 & 6.75 & 31.5 & 36 & & \\
\hline & GRA & 23 & 15 & 9 & 3 & 14 & 16 & & \\
\hline & Suburbs & 46 & 30 & 18 & 6 & 28 & 32 & & \\
\hline & Villages & 43.13 & 28.13 & 16.88 & 5.63 & 26.25 & 30 & & \\
\hline & Slums & 66.13 & 43.13 & 25.88 & 8.63 & 40.25 & 46 & & \\
\hline \multirow[t]{5}{*}{$\mathbf{O}-\mathbf{E}$} & City centre & 98.25 & -33.75 & -20.25 & -6.75 & -1.5 & -36 & & \\
\hline & GRA & 57 & -15 & -9 & -3 & -14 & -16 & & \\
\hline & Suburbs & -46 & 10 & 2 & 4 & 12 & 18 & & \\
\hline & Villages & -43.13 & 21.87 & 13.12 & 4.37 & -6.25 & 10 & & \\
\hline & Slums & -66.13 & 16.87 & 14.12 & 1.37 & 9.75 & 24 & & \\
\hline \multirow{5}{*}{$\begin{array}{l}(\mathbf{O} \\
\mathbf{E})^{2}\end{array}$} & City centre & 9653.06 & 1139.06 & 410.06 & 45.56 & 2.25 & 1296 & & \\
\hline & GRA & 3249 & 225 & 81 & 9 & 196 & 256 & & \\
\hline & Suburbs & 2116 & 100 & 4 & 16 & 144 & 324 & & \\
\hline & Villages & 1860.2 & 478.3 & 172.13 & 19.2 & 39.06 & 100 & & \\
\hline & Slums & 4373.18 & 284.6 & 199.37 & 1.88 & 95.06 & 576 & & \\
\hline \multirow{5}{*}{$\begin{array}{l}(\mathbf{O} \\
\mathbf{E})^{2} / \mathbf{E}\end{array}$} & & 186.53 & 33.75 & 20.25 & 6.75 & 0.07 & 36 & & \\
\hline & & 141.26 & 15 & 9 & 3 & 14 & 16 & & \\
\hline & & 46 & 3.33 & 0.22 & 2.67 & 5.14 & 10.13 & & \\
\hline & & 43.13 & 17 & 10.2 & 3.41 & 1.49 & 3.33 & & \\
\hline & & 66.13 & 6.6 & 7.7 & 0.22 & 2.36 & 12.52 & & \\
\hline
\end{tabular}

$\mathbf{H}_{\mathbf{2}}$ : There is a significant relationship between indiscriminate waste disposal and the existence of unplanned settlements in the NDR of Nigeria.

In this hypothesis, the table value is 31.41 at an alpha level of 0.05 with a degree of freedom (DF) of 20. The calculated value is 723.19 . This shows that the calculated value is greater than the table value. Hence, we accept the hypothesis $\left(\mathrm{H}_{2}\right)$ which states that there is a significant relationship between indiscriminate waste disposal and the existence of unplanned settlements in the NDR of Nigeria. Therefore, it implies that though, there are other factors that are encouraging indiscriminate waste disposal in the NDR of Nigeria but the existence of unplanned settlements in the region is one of the major factors that are bringing about the continuous act of indiscriminate waste disposal. 
Table 4. Analysis of hypothesis three $\left(\mathrm{H}_{3}\right)$

\begin{tabular}{|c|c|c|c|c|c|}
\hline \multirow[t]{2}{*}{ Formula } & \multirow[t]{2}{*}{ Category of Respondents } & \multicolumn{3}{|c|}{ Response Options } & \multirow[t]{2}{*}{ Total } \\
\hline & & Yes & No & Partially paved & \\
\hline \multirow[t]{6}{*}{$\mathbf{O}$} & City centre & 160 & 0 & 20 & 180 \\
\hline & GRA & 80 & 0 & 0 & 80 \\
\hline & Suburbs & 40 & 70 & 50 & 160 \\
\hline & Villages & 0 & 120 & 30 & 150 \\
\hline & Slums & 0 & 230 & 0 & 230 \\
\hline & Total & 280 & 420 & 100 & 800 \\
\hline \multirow[t]{5}{*}{$\mathbf{E}$} & City centre & 63 & 94.5 & 22.5 & \\
\hline & GRA & 28 & 42 & 10 & \\
\hline & Suburbs & 56 & 84 & 20 & \\
\hline & Villages & 52.5 & 78.75 & 18.75 & \\
\hline & Slums & 80.5 & 120.75 & 28.75 & \\
\hline \multirow[t]{5}{*}{$\mathbf{O}-\mathbf{E}$} & City centre & 97 & -94.5 & -2.5 & \\
\hline & GRA & 52 & -42 & -10 & \\
\hline & Suburbs & -16 & -14 & 30 & \\
\hline & Villages & -52.5 & 41.25 & 11.25 & \\
\hline & Slums & -80.5 & 109.25 & -28.75 & \\
\hline \multirow[t]{5}{*}{$(\mathbf{O}-\mathbf{E})^{2}$} & City centre & 9409 & 8930.25 & 6.25 & \\
\hline & GRA & 2704 & 1764 & 100 & \\
\hline & Suburbs & 256 & 196 & 900 & \\
\hline & Villages & 2756.25 & 1701.56 & 126.56 & \\
\hline & Slums & 6480.25 & 11935.56 & 826.56 & \\
\hline \multirow[t]{5}{*}{$(\mathrm{O}-\mathrm{E})^{2} / \mathrm{E}$} & & 149.35 & 94.5 & 0.28 & \\
\hline & & 96.57 & 42 & 10 & \\
\hline & & 4.57 & 2.33 & 45 & \\
\hline & & 52.5 & 21.61 & 6.75 & \\
\hline & & 80.5 & 98.85 & 28.75 & \\
\hline
\end{tabular}

$D F=(m-1)(n-1)=(3-1)(5-1)=2 * 4=8$, Alpha level of 0.05, Table value is 15.51, Calculated value is 733.56

$\mathbf{H}_{3}$ : There is a significant relationship between the absence of paved and or good road network in most parts of the cities in the NDR of Nigeria and inadequate waste collection and disposal services.

This hypothesis verifies the role of paved and or good road network in a city with respect to adequate waste collection and disposal. Here, the calculated value is 733.56 at an alpha level of 0.05 with a DF of 8; and the critical table value is 15.51 . Therefore, since the calculated value is greater than the critical table value, the hypothesis which states that there is a significant relationship between the absence of paved and or good road network in most parts of the cities in the NDR of Nigeria and inadequate waste collection and disposal services is accepted. We therefore, deduce that the absence of paved and or good road network in most parts of the cities in the NDR of Nigeria and inadequate waste collection and disposal services is significantly related.

\subsection{Discussion}

Following the results from the data acquired in course of this research, the following findings were made:

The research revealed that about $29 \%$ of the respondents live in various slums in the Niger Delta, $23 \%$ of respondents are living at the various city centres within the study area, $19 \%$ of the respondents live in villages while $20 \%$ of the respondents live in suburbs of the cities within the study area and only about $10 \%$ of respondents live in government reserved areas (GRA). This implies that a greater percentage of the people in the NDR are living in slums, and villages as well as low income areas of the various cities. 
The study also revealed that some of the causes of indiscriminate waste disposal in the NDR of Nigeria are existence of slums and unplanned settlements with about $21 \%$ of the respondents concurring to it. Absence of paved or good road network in the region is the next factor identified in this research as one of the causes of indiscriminate waste disposal in the region. Again, inadequate waste collection is another major factor that is encouraging indiscriminate waste disposal in the region and absence of facilities and WM infrastructure is also seen as a contributing factor to the problem of indiscriminate waste disposal in the Niger Delta. Furthermore, the study discovered that inadequate waste collection in the NDR of Nigeria is strongly linked with the existence of slums and unplanned settlements, as well as absence of paved or good road network, inadequate facilities and infrastructure, inadequate funding and inadequate trained personnel, see figure 8 and 9 .

In the NDR, waste collection services are concentrated at the residents where people of high and middle income earners are living (government reserved areas and city centres), while suburbs, slums and villages receives little or no waste collection service. This was evidence from respondents responses, as about $88 \%$ of the respondents who live in suburbs of the cities answered that wastes are never collected at their residents, while $100 \%$ of respondents who live in villages and slums responded that they never receive waste collection services, see figure 7. This act has led to the unabated occurrence of indiscriminate waste disposal and the presence of huge volumes of wastes on the streets, rivers and lakes in the NDR.

Just like the waste collection services, paved or good road network in the NDR is unevenly distributed. People living in villages and slums have partially paved roads or no good road networks. This unavailability of paved or good road networks in villages and slums is hindering waste collection and disposal services at these places, because waste collection vehicles and the waste collection workers can hardly get to these areas to collect the wastes for processing and disposal, see figure 9 .

\section{Conclusion}

This study established the understanding of the problem of MSWM in the NDR of Nigeria and its relationship with inadequate implementation of urban planning procedures during the building and development of cities in the region. Different government regimes in the Niger Delta have attempted to check the problem of inadequate WM in the region with little or no success. Despite the abundant resources in the region, funding of developmental projects such as roads and WM infrastructure has being under funded over the years. However, with the recent success story of WM in Calabar and Uyo city, other Niger Delta cities have also commence in earnest looking into solving the problem of WM.

Nevertheless, these efforts are continuously being plagued with the existence of unplanned settlements, slums, and shanty settlements within and around the major cities in the region. These unplanned settlements usually do not have good paved roads and are built haphazardly. This characteristic is the same in most Niger Delta settlements and cities in other regions of Nigeria. This unplanned nature of the settlements in the region as well as the absence of WM facilities have hindered WM agencies and companies to adequately collect, transport and dispose of the wastes generated from these places. This situation has led to the unabated problem of indiscriminate waste disposal, inadequate waste collection and general waste management processes.

In order to ensure the success of WM in the region's cities, good paved road networks should be built in all the cities, suburbs linking all other settlements in the region. New and old cities in the region should be planned properly with integration of WM strategies. Waste collection facilities and processes should be in proximity to the people. WM processes and infrastructure should be adequately funded. To achieve adequate compliance, the people should be part of the WM planning process and enlightenment programmes with regard to WM issues should be carried out in the region.

The need to urgently look into the problem of inadequate WM which is contributing in a great deal to the pollution and defacing of the cities in the region has become eminent now than ever, since the region is currently making efforts to develop its economy through tourism.

\section{References}

Agarwal, S. (2009). On finding the most statistically significant substring using the chi-square measure. Master's thesis, Indian Institute of Technology, Kanpur.

Agunwamba, J. C. (1998). Solid waste management in Nigeria: Problems and issues. Environmental Management, 22(6), 849-856. http://dx.doi.org/10.1007/s002679900152

Amnesty International, Nigeria: Petroleum Pollution and Poverty in the Niger Delta', United Kingdom: Amnesty International Publications International Secretariat. (2009). p. 10. 
Amnesty International. (2010). 200,000 Port Harcourt's residents at risk of homelessness. Retrieved June 3, 2013, from http://nigeriansabroadlive.com/200000-port-harcourts-residents -at-risk-of-homelessness

Botkin, D. B., \& Kelly, E. A. (1998). Environmental Science: Earth as a Living Planet (2nd ed.). John Wiley and Sons Inc, New York.

Centre for Environment, Human Rights and Develoment CEHRD. (2008). Human Right Report, Nigeria.

Centre for Population and Environmental Development CPED. (2003).

Coffey, M., \& Coad, A. (2010). Collection of Municipal Solid Waste in Developing Countries. UN-HABITAT, Malta.

Cohen, B. (2004). Urban growth in developing countries: A review of current trends and a caution regarding existing forecasts. World Development, 32(1), 23-51. http://dx.doi.org/10.1016/j.worlddev.2003.04.008

Communities and Local Governments. (2011). Planning Policy Statement 10: Planning for Sustainable Waste Management. The Department for Communities and Local Government, under licence from the Controller of Her Majesty's Stationery Office, United Kingdom.

CRS Report for Congress, Nigeria: Current Issues Updated January 30, (2008)

Denise, A. M. R., \& Vandenbogaert, M. (2001). Assessing the statistical significance of overrepresented oligonucleotides. WABI, 537-552.

Dutta, S., \& Bhattacharya, A. (2010). Most significant substring mining based on chi-square measure. PAKDD, 319-327.

Dutta, S., \& Bhattacharya, A. (2012). Mining statistically significant substrings based on the chi-square measure. In Pattern Discovery Using Sequence Data Mining: Applications and Studies, 73-82. IGI Global.

Egunjobi, L. (1986) 'Human Elements in Urban Planning and Development: Ibadan'. Habitat International, 10(4), 147-153. http://dx.doi.org/10.1016/0197-3975(86)90079-2

Egunjobi, T. O. (1986) Problems of solid wastes management in Nigeria urban centres. In E. A. Adeniyi, \& I. B. Bellow Imam (Eds.), Proceedings of National Conference on Development and Environment (pp. 74-92). Ibadan: NISER.

Environmental Resources Managers Limited ERML. (1997). Environmental and Socioeconomic Characteristics of the Niger Delta.

EPA. (1999). Copenhagen with European Commission Environment Directorate-General. Wasteguide, Framework and strategies for waste management in European cities.

Ezeah, C., Roberts, C. L., Watkin, G. D., Philips, P. S., \& Odunfa, A. (2009). Analysis of barriers affecting the adoption of a sustainable municipal solid waste management system in Nigeria. In the proceedings of the 24th International Conference on Solid Waste Technology and Management, 12 - 15 March, 2009, Widener University, Philadelphia, P.A, USA, pp. 1556-1564.

Geradu, J. (1995). Spatial planning and the environment, IPC 681, The Netherlands Ministry of Hunsing.

Goonatilake, R., Herath, A., Herath, S., Herath, S., \& Herath, J. (2007). Intrusion detection using the chi-square goodness-of-fit test for information assurance, network, forensics and software security. J. Computing Sciences, 23(1), 255-263.

Grbich, C. (2007). Qualitative Data Analysis: An Introduction. London: Sage Publications Ltd.

Henry, R. K., Yongsheng, Z., \& Jun, D. (2006). Municipal solid waste management challenges in developing countries - Kenyan case study. Waste Management, 26(1), 92-100. http://dx.doi.org/10.1016/j.wasman.2005.03.007

Imam, A., Mohammed, B., Wilson D. C., \& Cheeseman, C. R. (2008). Solid waste management in Abuja, Nigeria. Waste Management, 28, 468-472. http://dx.doi.org/10.1016/j.wasman.2007.01.006

Isu, B. A. (2005). The pains of waste .A Paper presented at the workshop organized by committee on vital Environmental Resources for Teachers/ Students, Eghosa Anglican Grammar School, Benin City.

Isumonah, V. A. (2013). Armed Society in the Niger Delta. Armed Forces \& Society, 39(2), 331-358. http://dx.doi.org/10.1177/0095327X12446925

Koehn, J. (1992). Waste Management in Nigeria Local Governments. International Conference on Energy, Environment and Disasters- INCEED2005, Charlotte, N.C, USA- pp 76-96. 
Konteh, F. H. (2009). Urban sanitation and health in the developing world: Reminiscing the nineteenth century industrial nations. Health \& Place, 15(1), 69-78. http://dx.doi.org/10.1016/j.healthplace.2008.02.003

Mabogunje, A. L. (1968). Urbanization in Nigeria. London: University of London Press.

Marshall, R. E., \& Farahbakhsh, K. (2013). Systems approaches to integrated solid waste management in developing countries. Waste Management, 33, 988-1003. http://dx.doi.org/10.1016/j.wasman.2012.12.023

Mosunmolu Limited. (1998). Flooding study of the Niger delta.

Mwesigye, P., Mbogoma, J., Nyakango, J., Idan, A. I., Kapindula, D., Hassan, S., \& Berkel, V. R. (2009). Integrated Assessment of Present Status of Environmentally -Sound Management of Wastes in Africa: Africa review report on waste management Main Report, United Nations Economic And Social Council, United Nations Industrial Development Organisation, Economic Commission For Africa, Sixth Session of the Committee on Food Security and Sustainable Development (CFSSD-6)/Regional Implementation Meeting (RIM) for CSD-18 Addis Ababa, Ethiopia 27-30 October 2009.

Nabegu, A. B. (2010). An Analysis of Municipal Solid Waste in Kano Metropolis, Nigeria. Journal of Human Ecology, 31(2), 111-119.

Napoleon, S. M., Kingsley, O. D., \& Joan, E. D. (2011). Mitigating the Impact of Solid Wastes in Urban Centres in Nigeria. Journal of Human Ecology, 34(2), 125-133.

NDDC. (2004). Niger Delta Regional Master Plan Final Report: Waste Management Sector.

Nkwocha, E. E., \& Okeoma I. O. (2009). Street Littering in Nigeria towns: Towards a framework for sustainable urban cleanliness. African Research Review, 3(5), 147-164.

Nkwocha, E. E., Pat-Mbano, E. C., \& Dike, M. U. (2004). Evaluating the Efficiency of Solid Waste Collection Services in Owerri Municipality, Nigeria. International Journal of Science and Nature, 2(1), 89-95.

Obafemi, A. A., Eludoyin, O. S., \& Opara, D. R. (2011). Road Network Assessment In Trans-Amadi, Portharcourt In Nigeria Using GIS. International Journal for Traffic and Transport Engineering, 1(4), 257264.

Odunfa, A. (2007). Municipal solid waste generation, transfer and disposal in Abuja. Interviewed by: Ezeah, C., via telephone from The University of Wolverhampton, Wolverhampton, $20^{\text {th }}$ December, 2007.

Ogwueleka, T. C. (2009). Municipal Solid Waste Characteristics and Management in Nigeria, Iran. J. Environ. Health. Sci. Eng., 6(3), 173-180.

Olowu, D. (1981). The Administration of Social Services in Nigeria: The Challenge to Local Government. Local Government Training Programme, University of Ile-Ife, Ile-Ife, Nigeria.

Onibokun, A. G., \& Kumuyi, A. J. (1998). Governance and Waste Management in Nigeria: The Case of Ibadan. In A. G. Onibokun (Ed.), Governance and Waste Management in Africa: A Comparative Perspective. (CASSAD), Ibadan.

Onu, B., Trevor, P., \& Suresh, S. S. (2014). Waste Management Motivational Factors in Bayelsa State. Change Management: An International Journal. Retrieved from http://www.Ontheorganization.Com

Onu, B., Trevor, P., Suresh, S. S., \& Ebie, S. (2012). Solid Waste Management: A Critique of Nigeria's Waste Management Policy. The International Journal of Knowledge, Culture and Change Management, 11(4). Retrieved from http://www.Management-Journal.com

Powell, I. (1995). Wildlife Study Report for Shell Petroleum Development Company (SPDC) of Nigeria.

Remigios, V. M. (2010). An Overview of the Management Practices at Solid Waste Disposal Sites in African Cities and Towns. Journal of Sustainable Development in Africa, 12(7).

Rocco, T. S., \& Plakhotnik, M. S. (2009). Literature Reviews, Conceptual Frameworks, and Theoretical Frameworks: Terms, Functions, and Distinctions. Human Development Review, 8(1), 120-130. http://dx.doi.org/10.1177/1534484309332617

Sachan, M., \& Bhattacharya, A. (2012). Mining Statistically Significant Substrings using the Chi-Square Statistic. Proceedings of the VLDB Endowment, Vol. 5, No. 10, August $27^{\text {th }}$ to $31^{\text {st }} 2012$, Istanbul, Turkey.

Stren, R., Halfani, M., \& Malombe, J. (1994). Coping with Urbanisation and Urban Policy. In J. D. Barkan (Ed.), Beyond Capitalism vs. Socialism in Kenya and Tanzania. Lynne Reinner Publisher, Boulder, Co, USA. 
Tacoli, C. (2012). Urbanization, Gender and Urban Poverty: Paid Work and Unpaid Carework in the City. International Institute for Environment and Development: United Nations Population Fund, London, UK.

UNFPA. (2011). State of World Population 2011: United Nations Population Fund.

United Nations Development Programme UNDP. (2006). Niger Delta Human Development Report, Nigeria.

United Nations Human Settlements Programme (UN-HABITAT). (2010). Solid Waste Management in the World's Cities, Water and Sanitation in the World's Cities, United Nations Human Settlements Programme. EarthScan, London. Washington, DC.

United Towns Development Agency. (1996). The Cities Environment Kit. A Training Guide in Local Environmental Policies for Technicians and Elected Officials in the Mediterranean.

Whittington, J. (2001). In the British Broadcasting Corporation (BBC) News, December, 2001.

Wolfville, P. J. R., \& Scotia, N. (2002). Study on Solid Waste Management Options for Africa. African Development Bank, Project Report Final Draft Version, Canada.

World Bank/METAP. (2002). Solid Waste Management Strategy for METAP Mashreq and Maghreb Countries.

\section{Copyrights}

Copyright for this article is retained by the author(s), with first publication rights granted to the journal.

This is an open-access article distributed under the terms and conditions of the Creative Commons Attribution license (http://creativecommons.org/licenses/by/3.0/). 